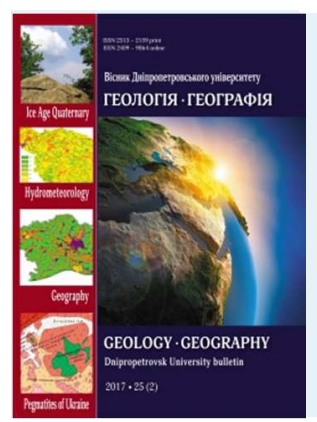

Volodymyr V. Manyuk

\section{Geology $\bullet$ Geography}

\section{Dnipro university bulletin}

Journal home page: geology-dnu-dp.ua
ISSN 2313-2159 (print) ISSN 2409-9864(online)

Dniprop. Univer.bulletin. Geology, geography., 25(2), 99-110. doi: $10.15421 / 111724$

Dniprop. Univer. bulletin, Geology, geography., 25(2), 99-110.

\title{
Про змінення положення південної границі Дніпровського (риського) зледеніння
}

\author{
Володимир В. Манюк
}

Дніпровський національний університет імені Олеся Гончара, Дніпро, Украӥна, е-таil:vgeoman@gmail.com

Received 16 September 2017

Received in revised form 17 October 2017

Accepted 07 November 2017
Резюме. На підставі нового фактичного матеріалу розглянуто питання кореляції положення південної межі поширення Дніпровського (риського) льодовикового язика, який вважається найбільш південним в Європі для риської льодовикової епохи. Наведено критичний аналіз історії становлення льодовикової теорії та роль у цьому вчених із різних країн. Простежено еволюцію поглядів дослідників від дрифтового походження валунно-суглинистих відкладів, висловлених у працях Р. Мурчісона, Ч. Лайєля, Д. Тіласа та Ч. Дарвіна до льодовикового, першими прихильниками якого були П'єр Мартель, Жан Андре Делюк, Бернард Фредерік Кун, Ігнас Венец, Альбрехт Бернарді, Луїс Агассіз та інші. Оцінено роль російських дослідників покривних зледенінь, серед яких перш за все П. О. Кропоткін, С. М. Нікітін, О. О. Іностранцев, П. Я. Армашевський, Н.І. Криштофович, Г.С. Щуровський, Ф.Б. Шмідт та інші. Враховано точку зору опонента льодовикової теорії В.Г. Пазинича щодо численних розбіжностей у трактуванні її основних положень та необхідності розробити комплексну модель зледенінь, яка б ураховувала і екзарацію і дрифт. Уперше наводяться результати вирішення складної проблеми відновлення геологічної пам'ятки природи «Домотканські валуни» як важливого об'єкта геологічної спадщини на південній границі Дніпровського льодовикового язика. Викладено нові результати дослідження гори Калитва як кінцевоморенного утворення, сформованого в дніпровську льодовикову епоху. Гора Калитва - яскравий приклад відображених у відкладах гляціотектонічних подій, моренних, флювіо- і лімногляціальних відкладів з ератичними валунами і палеогеновими відторженцями. Обгрунтовано можливість розчленування Дніпровського кліматоліту на нижньо,- середньо- та верхньодніпровський стадіали та показано відповідність озерно-льодовикових, моренних та флювіогляціальних відкладів середньодніпровського стадіалу середній і верхній пачкам «шевченківської світи». Встановлено, що перигляціальна зона, розташована південніше лінії Вільногірськ - Петриківка - Юр'їкка, відрізняється відсутністю валунних суглинків, значно більш однорідним і витриманим розрізом субаеральних четвертинних відкладів, але наявністю лінз флювіогляціальних відкладів. Виявлене штучне відслонення лімногляціальних відкладів між селами Спаське і Підгороднє дозволяє не тільки побачити виразні ознаки відмінності еолових і озерних суглинків, а й вточнити межу перигляціальної зони дніпровського зледеніння, яка раніше проводилася майже на 100 км північніше - у пригирловій частині р. Оріль. Польовими дослідженнями у межиріччі річок Дніпро - Кільчень - Самара встановлено переконливі докази необхідності проведення південної границі перигляціальної зони дніпровської льодовикової епохи значно південніше прийнятої.

Ключові слова: дніпровське зледеніння, рис, дрифт, флювіогляціальний, полігляціалізм, ератичні валуни

\section{On reassigning the location of the southern border of the Dnieper (Riss) Glaciation}

\author{
Volodymyr V. Manyuk \\ Oles Honchar Dnipro National University,Dnipro,Ukraine, e-mail: vgeoman@gmail.com
}

\begin{abstract}
On the basis of newly discovered factual material, this paper analyses the issue of the reassigning the position of the southern border of distribution of the Dnieper (Riss) glacial tongue, which is considered the southernmost glacier tongue of the glacial period in Europe. The article provides critical analysis of the history of glacial theory and the contribution of scientists from different countries. The article analyses the evolution of the views of researchers - from the drift origin of boulder-loam deposits, described in works by R Murchison, C Lyell, D Tilas and C Darwin, to the idea of glacial origin, the first supporters of which included Pierre Martel, Jean-André Deluc, Bernhard Friedrich Kuhn, Ignaz Venets, Albrecht Bernardi, Louis Agassiz and others. The paper evaluates the contribution of Russian scientists who studied continental glaciations, including P O Kropotkin, S M Nikitin, O O Inostrantsev, P Y Armashevsky, N I Krishtofovich, G E Shurovsky, F B Schmidt and others. The article also presents the position of V G Pazynych, an opponent of glacier theory, on the numerous differences of opinion in the interpretation of the framework of the theory and on the necessity of developing a complex model of glaciations, which would include consideration of both exaration and drift. This article presents for the first time the results of solving the problem of restoring the geological relic, the "Domotkanski valuny" [lit. Domotkan boulders - translator`s note] as an important object of geological heritage on the southern border of the Dnieper glacial tongue. The paper presents a study of Kalytva mountain as a terminal moraine formation, which was
\end{abstract}


formed during the Dnieper glacial epoch. Kalytva mountain is a fine example of manifestations of glaciotectonic activities, moraine, fluvio- and limno - glacial deposits with erratic boulders and paleogenic outliers. The article proves the possibility of division of the Dnieper climatolith into lower, -middle, and upper Dnieper stadials and shows the correspondence of limno-glacial deposits, moraine and fluvio-glacial deposits of the middle Dnieper stadials to the upper part of the "Shevchenkivska suite". We have shown that the periglacial zone situated to the south of the line Volnohorsk-Petrykivka-Yurivka is characterized by absence of boulder loams, by much more homogenous and weathered section of sub-aerial Quaternary deposits and by a lens of fluvio-glacial deposits. The discovery of the artificial outcrop of limno glacial moraine deposits between Spasske and Podhorodne villages enables us not only to determine the main clearly-manifested differences between eolian and limnetic loams but also to delineate more precisely the borders of the periglacial zone of the Dnieper glaciations, which was earlier marked almost $100 \mathrm{~km}$ to the north - in the region of the Orel river far from its confluence with the Dnieper. Field studies in the interfluve between the Dnieper, Kilchen and Samara found significant evidence for proving that the southern border of the periglacial zone of the Dnieper Glacial Epoch lies considerably further south than had been assumed previously.

Keywords: Dnieper glaciation, Riss, drift, fluvioglacial, polyglacialism, erratic boulders

Вступ. Навколо ідеї існування великих материкових зледенінь завжди точилася дискусії, а в останні роки тенденція до спростування цієї ідеї помітно посилилася. Як і раніше вона породжує велике коло поглядів - від полігляціалізму, що стверджує множинність зледенінь, до теорії антигляціалізму, якою спростовуються будь-які масштабні зледеніння. Ознаки присутності льодовика в Північній і Центральній Україні достатньо переконливі і для переважної більшості дослідників цього явища не викликають сумнівів. Щодо визнання кількох наступів льодовика, то воно наче існує, але тут доказова база дуже не достатня і проблему старанно обходили й геологи минулих поколінь, і сучасники. Зусилля вчених зосереджувалися на всебічному вивченні дніпровського зледеніння, яке залишило по собі і потужні морени, і прояви гляціодислокацій, флювіо- і лімногляціальні відклади, виразні екзараційні йі акумулятивні форми рельєфу льодовикового походження. В останні роки накопичений новий фактичний матеріал, аналіз якого свідчить про можливість кореляції південної межі поширення дніпровського льодовикового язика (Manyuk, 2017).
Історія питання. Історія становлення льодовикової теорії була досить складною, цікавою, тривалою і неоднозначною. Чомусь вважається, що першим припустив, що ератичні валуни поблизу Гронінгена були залишками корінних порід, які були зруйновані потужною повінню (потопом), французький геолог і метеоролог Жан Андре Делюк. Втім, перша його робота геологічного плану датована 1810 роком. Лише в 1773 p. він покинув бізнес у Женеві, переїхав у Англію і почав вивчати геологію (De Luc, 1810).

У 1742 році П'єр Мартель, інженер та природничник, який жив у Женеві, відвідує долину Шамоні, утворену р. Арві у Савойських Альпах. Двома роками пізніше, звітуючи про свою подорож він повідомляє, що мешканці долини пояснюють наявність численних розкиданих валунів дією льодовика і що колись ці валуни були набагато далі від сучасного їх положення (Martel, 1744). За свідченням П. Мартеля, льодовики 3 Льодовикової долини не завжди мали такі розміри, вони то збільшувалися, то зменшувалися. Згідно з реперами, що вони залишили по собі, потужність льодовиків була на 80 футів більшою ніж зараз (рис. 1).

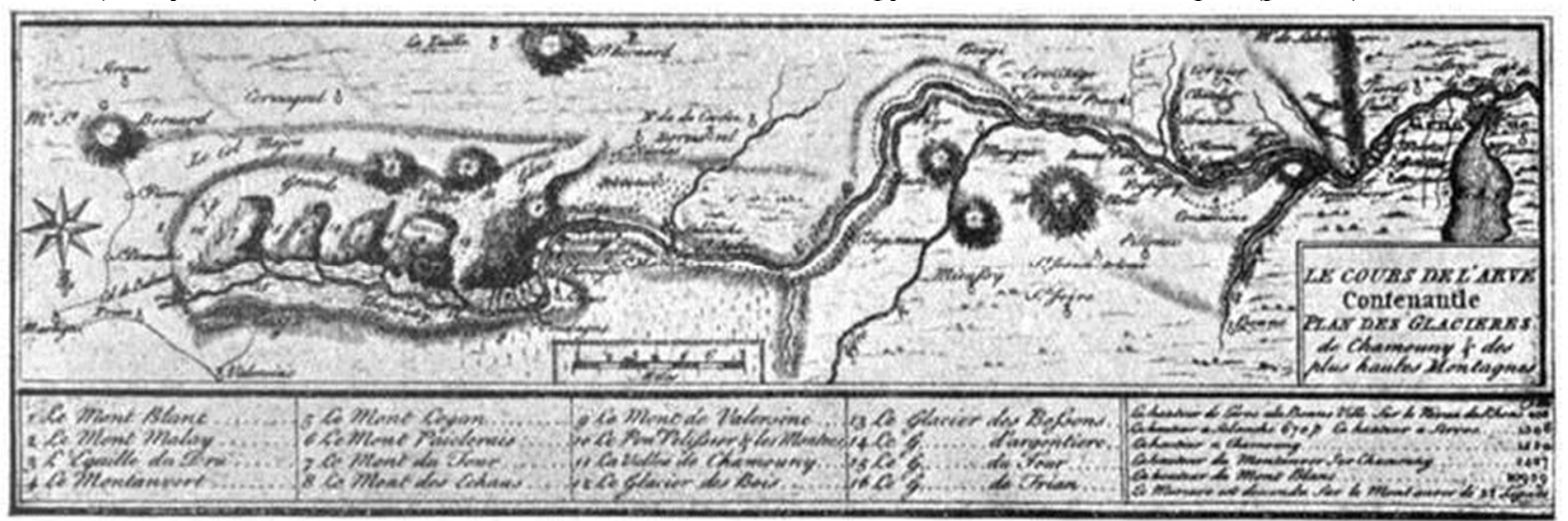

Рис. 1. Карта льодовиків Шамоні та найвищих гір на південь уздовж долини річки Арві (Martel, 1744)

Втім, більшість європейських учених висловлювали зовсім інші погляди щодо транспортувальної дії льоду. Швейцарський гірничий інженер Даніель Тілас у 1742 р. першим припустив можливість переміщення ератичних валу- нів у Скандинавському і Балтійському регіонах дрейфуючим льодом (drifting sea ice), започаткувавши «теорію дрифтингу» (Kruger, 2013a).

У 1795 році шотландський філософ, натураліст Джеймс Хаттон припустив, що ератич- 
ні валуни в Альпах переміщені дією льодовиків (Saussure, 1796). У 1797 році Бернард Фредерік Кун опублікував вражаюче «сучасний» погляд на динаміку льодовика, випередивши на 30-40 років роботи I. Веніса та інші (Kuhn, 1787) (рис. 2).

Горацій-Бенедикт де Coccep (HoraceBenedict de Saussure) разом 3 іншими вченими, серед яких Деодат де Доломеу, Карл Лінней, П.С. Палас, звертається до «ератичних пазлів», тобто досліджує ератичні валуни. Він вважав, що валуни транспортувала вода і припускав, що це могли б бути припливні велетенські хвилі висотою 4800 футів, які переміщували блоки

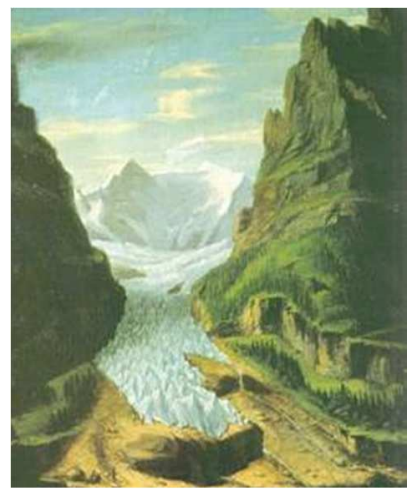

Рис. 2. Нижній льодовик Гріндельвальд на початку XIX ст.: один із льодовиків, які вивчав Кун. Зараз він відступає. Акварель Дж. Х. Аберді, 1762. (http://users.unimi.it/glaciol/glaciologia/ghicon.html).

Жорж Кюв’є, якого називають «батьком палеонтології», засновником і прихильником катастрофізму, ретельно вивчав викопні фосилії, використовував порівняльну анатомію i зробив вікно у минуле життя планети, чим, за свідченням сучасників, зачарував публіку (рис. 3).

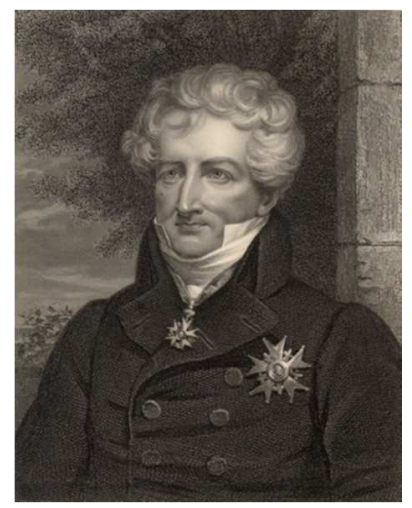

Рис. 3. Жорж Кюв’є

Ж. Кюв'є писав, що він бачить свідчення сучасної, заключної геологічної революції (ма- порід на ці гори (Альпи) (Saussure, 1796). Джон Плайфер у праці «Ілюстрації до теорії Землі Геттона» (Playfair, 1802), присвяченій аналізу поглядів його друга філософа і геолога Дж. Геттона (Хаттона), критично ставиться до теорії водних потоків як транспорту для переміщення ератичних валунів в Альпах. Він пояснює рух валунів комбінацією інтенсивної гляціальної ерозії, швидких потоків із більш високих у ті часи Альп, та інтенсивної денудації. Безумовно необхідною він вважав наявність проривних потоків із підпрудних водоймищ того часу (Playfair, 1802).

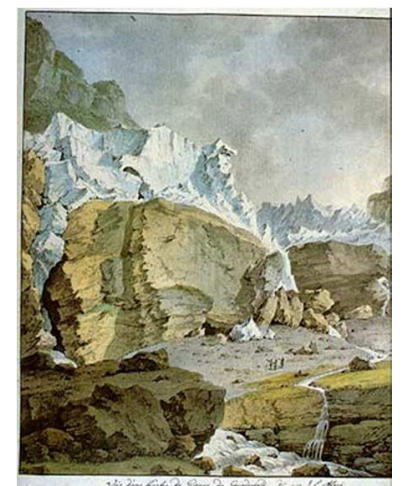

терикове зледеніння), поверхневі поклади якої перекрили осадові формації третинного періоду. Ці поклади, писав Ж.Кюв'є, містять залишки чисельних вимерлих ссавців, таких як носороги, слони, гієни (Cuvier, Brongniart, 1811).

Прусський натураліст Леопольд фон Бух, визнаний у світі геолог, праці якого перекладені на багато мов світу, у 1810 р. вивчав походження ератичних валунів у Юрських горах $\mathrm{i}$ простежив шлях переміщення найбільших гранітних брил поблизу м. Нейшатель та в інших місцях. Після декількох років польових досліджень він доходить висновку, що валуни переміщені потужними грязьовими потоками (лахарами), які виникали під час проривів велетенських підгачених озер (Buch, 1819). Явище утворення підгачених озер пов'язане із пульсаціями льодовика, різкими збільшеннями швидкості його руху i отримало назву «сьордж» (рис. 4) 

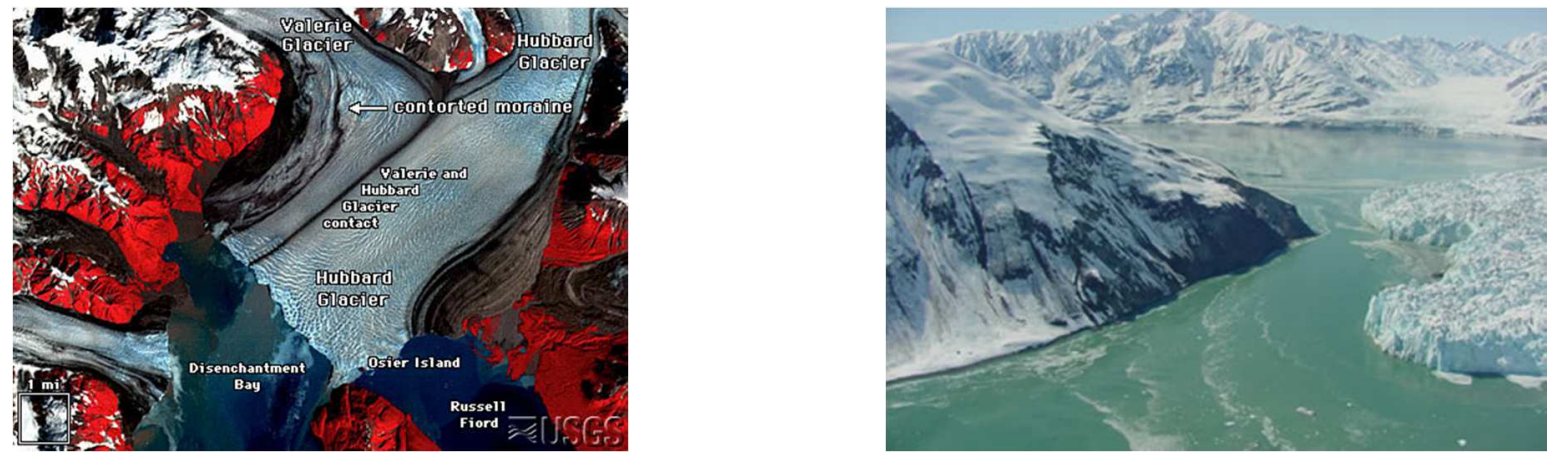

Рис. 4. Процес перетворення Рассел-фіорду на льодовиково-підгачене озеро (https://www.fs.usda.gov/detail/r10/aboutregion/overview/?cid=fsbdev2_038669)

Видатний шотландський геолог, геофізик і філософ Джеймс Холл, відомий експериментальними роботами із виверженими породами у статті, надрукованій у 1812 р., успішно поєднує циклічність порід Геттона (Хаттона) з вирішенням проблеми Альпійських ератичних валунів (erratics) та деякими іншими проблемами того часу. Розігрів у надрах Землі викликає періодичне розширення, землетруси, виверження вулканів та, відповідно, в морях вони викликають велетенські хвилі, які Д. Холл назвав «дилювіальними» (Hall, 1812).

У 1815 році тесляр і мисливець Жан П'єр Преродін (1767-1858) пояснював ератичні валуни у Вал де Б'янсі тим, що тут раніше були льодовики (Kruger, 2013b). Схожу ідею, як відомо, висловлював дроворуб із Мейрінгена у Бернських Альпах під час дискусії із швейцарсько- німецьким геологом Жаном Шерпант'є у 1834 p. (Kruger, 2013c). Подібні пояснення ві- домі також від Вал де Феррета із Східної Швейцарії та із праць Гете.

Датсько-норвезький геолог Йєнс Есмарк у статті, датованій 1824 р., пропонує вважати змінення клімату причиною зледенінь та намагається показати, що вони є наслідком періодичних змін орбіти Землі (Krüger, 2013d). У 1829 році, швейцарський інженер Ігнац Венетс пояснює поширення ератичних валунів в Альпах, поблизу Юрських гір та в межах ПівнічноНімецької рівнини наслідком роботи великих льодовиків (рис. 5). Коли він зробив доповідь 3 цього приводу у Швейцарській академії природничих наук, більшість учених скептично поставились до ідеї (Andersen, 1992). I. Венетсу вдалося переконати у справедливості своїх поглядів друга Жана Шерпантьє, який трансформував ідею Венетса в теорію великого зледеніння в Альпах (Venetz, 1821).

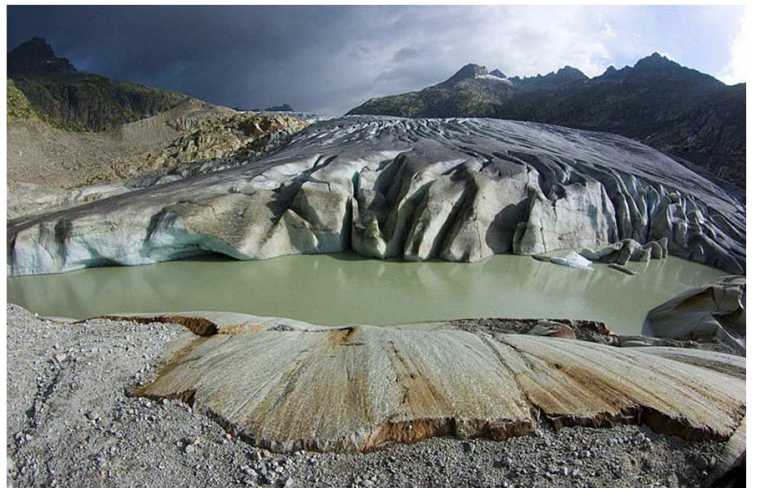

Рис. 5. Моренні пасма біля Сімплона в Альпах із карти Венетса (Venetz, 1833) та утворення нового підгаченого озера біля язика льодовика Рона на Алясці (Glaciers, 2017)

Не можна не згадати і статтю 1832 p. Альбрехта Рейнгарда Бернарді, у якій він розмірковує щодо колишніх льодовикових покривів (polar ice caps), які сягали помірних широт земної кулі (Bernardi, 1832).
У той же час німецький ботанік Карл Фредерік Шимпер вивчав мохи, які росли на ератичних валунах в альпійських нагір'ях Баваpiï, i був здивований такою масою розкиданого каміння. Шимпер дійшов висновку, що льод мав би бути засобом транспортування валунів у 
Альпійському нагір'ї. Шимпер провів літні місяці 1836 р. у Девенсі в Швейцарських Альпах 3 колишнім університетським другом Луїсом Агассізом (1807-1873) та Жаном де Шерпантьє. Взимку 1836 - 37 років Агассіз і Шимпер розробили теорію періодичних зледенінь. На той час Л. Агассіз, схоже, вже був знайомий із статтею А. Бернарді (Kruger, 2013е). У 1837 р. К. Шимпер упроваджує термін «льодовикова епоха» (ice age, або нім. Eiszeit) для періоду зледенінь. В липні 1837-го Агассіз представляє його робо- ту до щорічної зустрічі Швейцарській академії природничих наук у м. Невшатель (рис. 6). Аудиторія сприйняла дуже критично викладену теорію, оскільки вона не відповідала сталій думці щодо історії клімату. Аби здолати це протистояння, Л. Агассіз вживає рішучих заходів до проведення нових геологічних маршрутів, за результатами яких публікує книгу «Вивчення льодовиків» («Etudes sur les glacier») у 1840 p. (Agassiz, 1838)

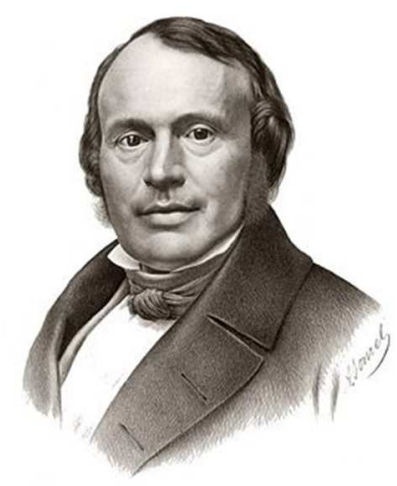

AUSZUG

AUS DEM BRIEF DES HERRN Dr SCHIMPER

UEBER DIE EISZEIT,

AN PR. AGASSIZ, PRESIDENT DER GESELLSCRATT ( ) , .

Рис. 6. Луїс Агассіз та його праця «Льодовикова епоха», яка вийшла друком у 1837 році

Навряд чи це сподобалося Ж. Шерпантьє, який ввів Агассіза у глибини гляціологічних досліджень і який на той час також підготував до друку книгу щодо льодовиків в Альпах, але то вже інша історія (Agassiz, 1840). Більш за те, Л. Агассіз, внаслідок приватних сварок, виключив із книги будь-які згадки про К. Шимпера (Kruger, 2013f). Книга декілька десятків років не підтримувалася вченими і лише у 1870 р. відбулося визнання теорії у міжнародному масштабі. Це стало можливим після публікації Джеймса Кролла «Клімат і час», яка дала надійне пояснення причин льодовикового періоду.

Перші докази на користь полігляціалізму в межах Середньоєвропейської рівнини надає німецький геолог і геоморфолог А. Пенк. Разом із німецьким гляціологом Е. Брюкнером він розробив концепцію давніх зледенінь, запропонував розподіл льодовикового періоду на льодовикові епохи - гюнц, міндель, рис та вюрм (Penck, Brückner, 1909) (рис. 7).

У Росії прихильниками полігляціалізму були Н. І. Криштофович, А. Д. Архангельський, тоді як погляди щодо однократного зледеніння сповідували П. О. Кропоткін, С. М. Нікітін, О. О. Іностранцев, П. Я. Армашевський. Слід зазначити, що серед полігляціалістів також не було єдності щодо кількості льодовикових етапів, у зв'язку з чим дослідники розділилися на помірних полігляціалістів та екстраполігляціалістів. На кінець ХIX століття накопичився великий обсяг фактичних матеріалів, аналіз яких дозволив здійснити якісний стрибок у розвитку науки. Майже одночасно виходять в світ узагальнювальні праці О. Торелла у Швеції, А. Гейки у Великій Британії, П. О. Кропоткіна в Росії. У Росії першими прихильниками ідеї развитку покривних льодовиків були Г.С. Щуровський та Ф. Б. Шмідт. 

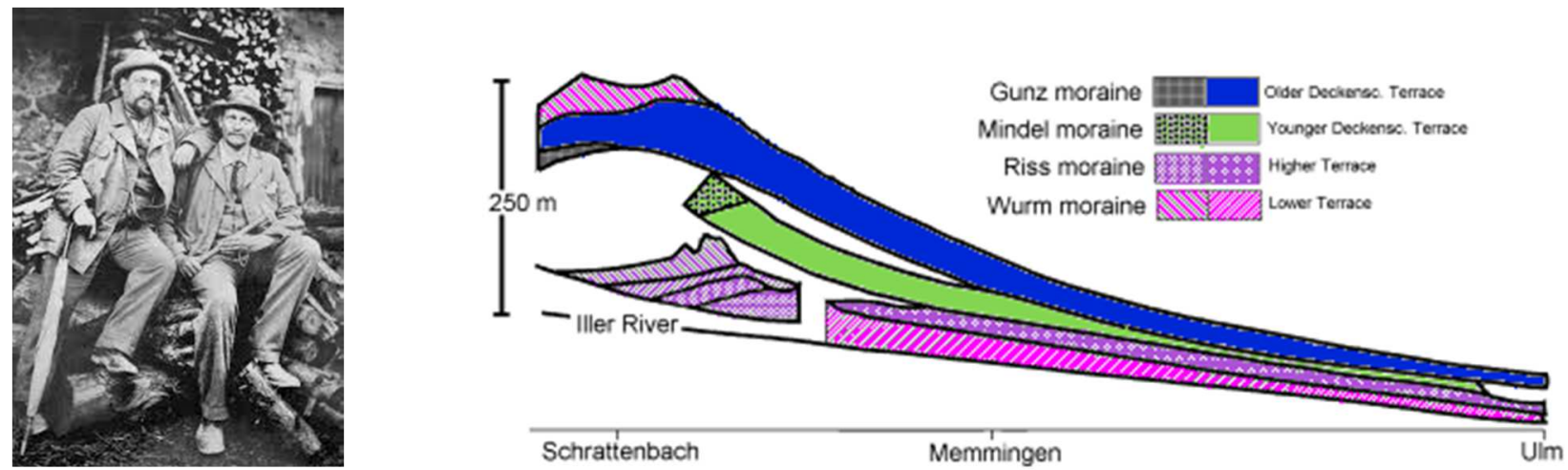

Рис. 7. А. Пенк та Б. Брюкнер - автори теорії полігляціалізму

Найбільшу роль 3 російських вчених в розвитку гіпотези покривних зледенінь зіграв П.О. Кропоткін. У 1874 році він зробив доповідь на засіданні Імператорського Російського географічного товариства про результати геологічного та географічного вивчення територій Сибіру і Скандинавії. На підставі проведених досліджень Кропоткін дійшов висновку, що названі регіони є областями давнього зледеніння. У 1876 році була опублікована його книга «Дослідження про льодовиковий період», де викладено основні положення льодовикової теорії (Kropotkin, 1876). У 1875 році шведський геолог Отто Торелл, грунтуючись на великому обсязі фактичної інформації щодо льодовиків Гренландії, Ісландії та Шпіцбергена, зробив висновок про недавне суцільне зледеніння Північної i Центральної Свропи. В даний час творцями льодовикової теорії називають саме П. О. Кропоткіна та О. Торелла.

Середнє Придніпров'я являє собою об- ласть зчленування зони поширення гляціальних відкладів (на півночі) з перигляціальними, головні риси будови яких сформовані у дніпровську (риську) льодовикову епоху з накладеними подальшими змінами постгляціального часу.

Матеріали і методи. Щодо південної межі найпотужнішого Дніпровського зледеніння, то іiї положення на карті залишається незмінним 3 1885 р., коли С.М. Нікітіним визначі іiі за поширенням ератичних валунів. Втім, Марков К.К. у праці «Палеогеография и новейшие отложения» (Markov, 1986), вказує В.В. Докучаєва як безпосереднього автора концепції «Дніпровського язика» (Pazynych, 2007). Докучаєв у праці «Наши степи прежде и теперь» писав: «Больше половины России было одето сплошным ледяным покровом. Скандинавско-Русский ледник далеко вдавался на юг в виде двух широких языков, из которых западный в настоящей статье будет называться днепровским, а восточный донским.» (Dokuchaev, 1892.) (рис. 8).
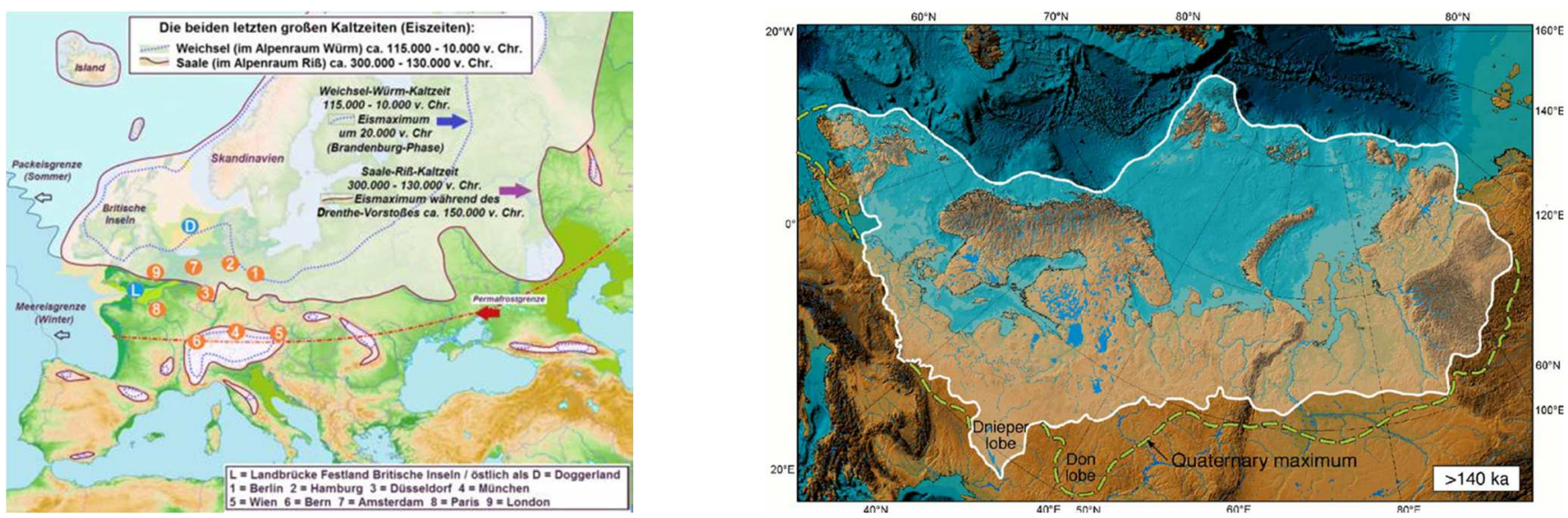

Рис. 8. Межі поширення риського (заальського, дніпровського) і вюрмського (вейшельського, вістульського) покривних льодовиків. Retrieved from: https://en.wikipedia.org/wiki/Saale glaciation;

https://www.researchgate.net/publication/235703913 Late Quaternary ice sheet history of northern Eurasia/figures?lo=1

Автор відомої праці «Геоморфологічний літопис Великого Дніпра» В.Г. Пазинич вважає, що безкомпромісна перемога материкового зле- деніння над дрифтовою теорією виявилися пірровою. На його думку більш правильним було б 
розробити комплексну модель, яка б ураховувала й екзарацію і дрифт (Pazynych, 2007).

У 1939 році у праці Герасимова І.П. та Маркова К.К. «Льодовиковий період на теритоpiï СРСР» границя зазнала несуттєвого уточнення і надалі ніколи не змінювалася (Gerasimov, Markov, 1939). За всіма літературними джерелами, більш західний з двох язиків льодовика сягав м. Дніпропетровськ, а більш точно широти м. Домоткань (координати 4842'49'). Це місце знаходження Домотканських ератичних валунів, які більш відомі під назвою Бородаївських. Назва була невдалою, бо насправді біля с. Бородаївка жодних валунів немає, і розташовані вони в 10 км на північний захід від с.
Домоткань (рис. 9). Сучасну долю валунів супроводжувала низка дивних історій. Спочатку, ще в далекому 1972 році вони були заповіданими, як геологічна пам'ятка природи місцевого значення «Бородаївські валуни». У 1991 році природоохоронний статус пам'ятки було скасовано на підставі неперевіреної інформації про їх знищення. Ще більш дивною була історія їх відродження. У 2013 році, з невідомих причин, рішенням Дніпропетровської обласної Ради раптом створено ландшафтний заказник «Домотканські валуни» загальною площею 826,67 га (для порівняння: перед скасуванням пам'ятки було 1 га).
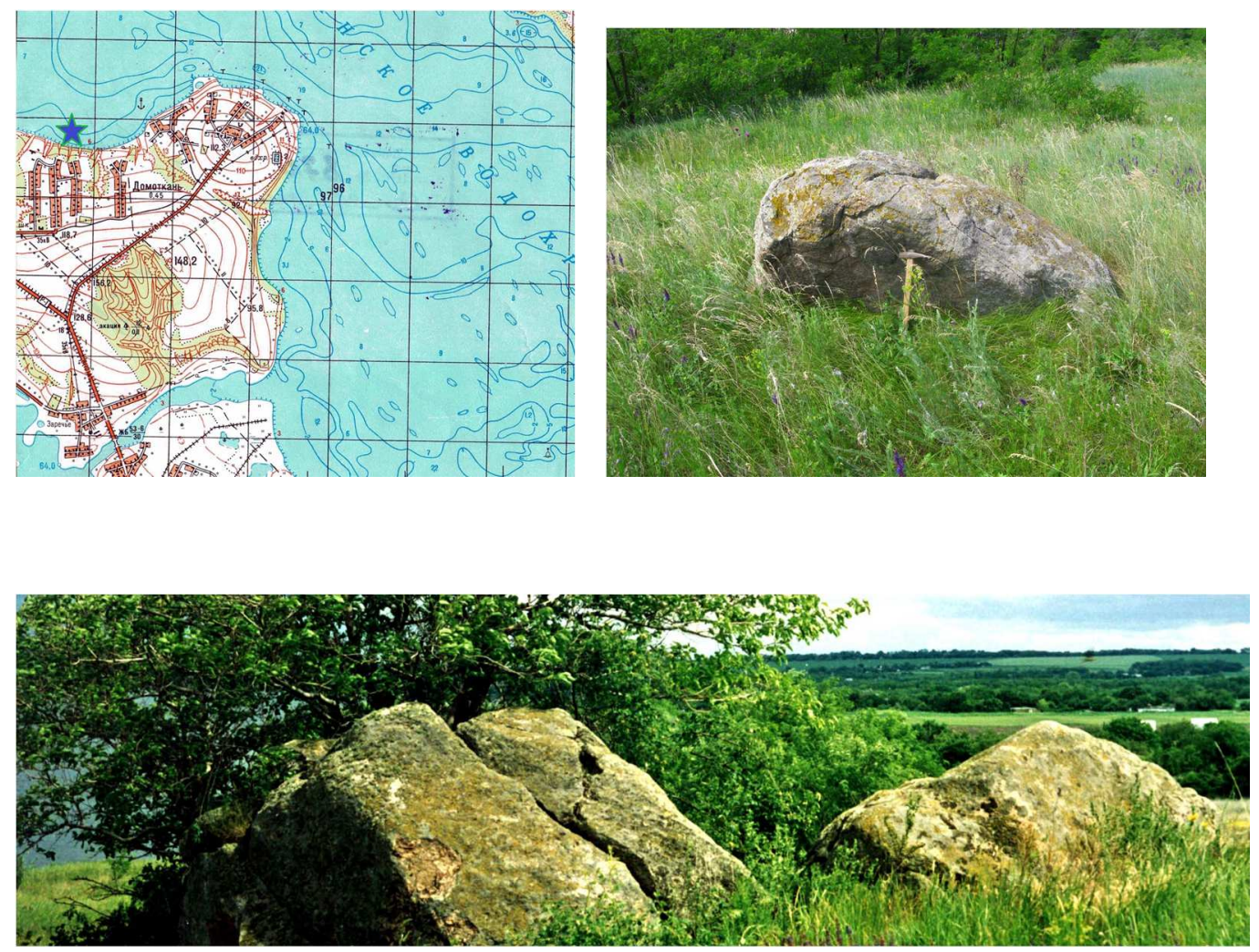

Рис. 9. Домотканські ератичні валуни на топографічній карті та на місцевості

Іншим об'єктом із виразними ознаками дніпровської (риської) льодовикової епохи на півночі Середнього Придніпров'я безумовно $€$ «Гора Калитва». Першим визнав гору як кінцевоморенне утворення А.Р. Ферхмін, виходячи 3 того, що валунний суглинок тут сягає великої потужності (17-20 м) та крім нього тут зустрічається велика кількість наметнів, як у ті роки називали ератичні валуни (Ferhmin, 1891). Він же вказував, що це найпівденніший пункт, якого сягав дніпровський льодовик. Така велика потужність валунних суглинків більш пізніми дослідженнями була спростована і Л.І. Карякін, який першим це показав, вважав, що «Гора Ка- литва» - продукт не тільки акумулятивної морени, а й напірної.

Пізніше, M.I. Дмитрієв доходить висновку, що попри те, що на Лівобережжі не виявлені, крім Калитви, відбиті у рельєфі прояви кінцевих морен, льодовик залишив їх насправді значно більше. Вони не виявлені у рельєфі тільки тому, що були знищені у вюрмську епоху, а в подальшому поховані лесовим покривом (Dmitriev, 1931).

Дослідженню одного з кращих в Україні витворів льодовикової епохи приділяли увагу впродовж майже півтора століття також Д.Н. Соболєв, Г.Ф. Мирчинк, В.Г. Бондарчук, П.К. Заморій , І.Г. Підопличко та інші. Значний обсяг 
робіт по дослідженню «Гори Калитви» був виконаний нами у 80-ті роки минулого сторіччя, коли під час геологічної зйомки були не тільки обстежені всі природні відслонення на схилах Калитви та у ярах, що ï розчленовують, а й пробурені свердловини, керн яких чудово де- монструє масштаб гляціодислокацій дніпровської льодовикової епохи. Четвертинний розріз тут представлений тільки середньою і верхньою ланками, відклади нижньої повністю знищені екзараційною роботою льодовика та флювіогляціальними потоками (рис. 10).

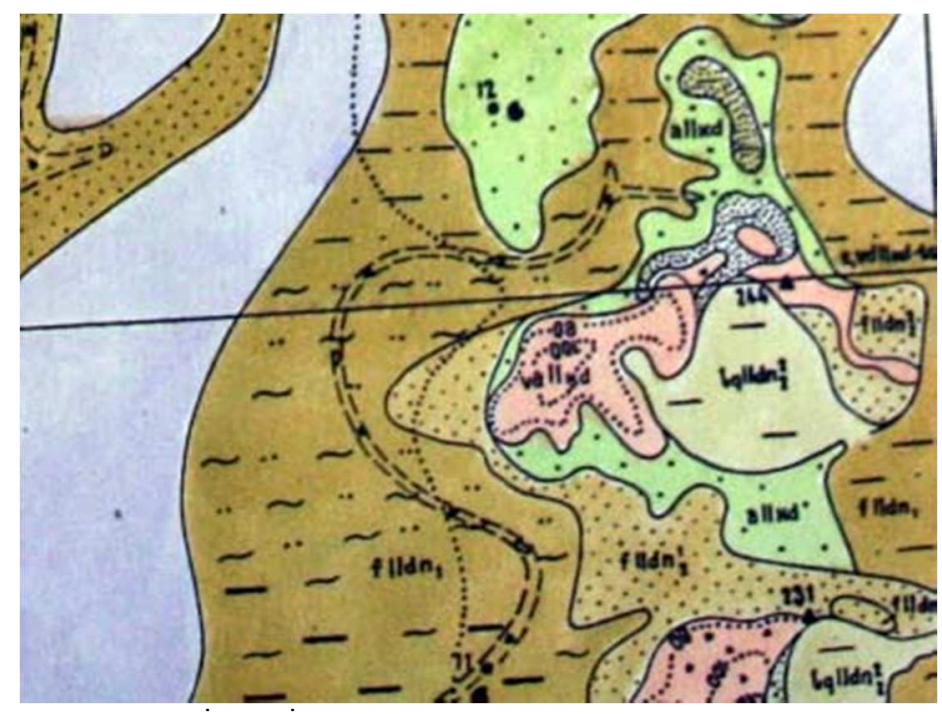

Рис. 10. Гора Калитва на карті четвертинних відкладів

a II kd - алювій кодацького кліматоліту середнього плейстоцену; e,vd II kd-ts - елювіальні та еолово-делювіальні відклади черкаського (кодацько-тясминського) ступеня; $\lg \mathrm{II} \mathrm{dn}_{2}^{2}$ - озерно-льодовикові відклади верхньої товщі середньодніпровського стадіалу; f II $\mathrm{dn}_{2}{ }^{1}$ - флювіогляціальні відклади нижньої товщі середньодніпровського стадіалу; f II dn ${ }_{1}$ - флювіогляціальні відклади нижньодніпровського стадіалу

Дніпровський кліматоліт складений льодовиковими утвореннями, які залягають на дочетвертинних відкладах та значно поширені у льодовиковій зоні. Дніпровський кліматоліт поділяється на нижньо-, середньо-, та верхньодніпровський стадіали. Нижньодніпровський стадіал складений флювіогляціальними осадками $\mathrm{fP}_{\text {II }} \mathrm{dn}_{1}$. Середньодніпровський стадіал представлений озерно-льодовиковими, моренними та флювіогляціальними відкладами, які відповідають середній і верхній пачкам «шевченківської світи» - $\lg \mathrm{P}_{\mathrm{II}} \mathrm{dn}_{2}$. Розріз нижньої частини середньодніпровського кліматоліту завершують озе- рно-льодовикові відклади, що перекривають донну морену. Верхньодніпровський стадіал представлений крайовою мореною - $\mathrm{gkP}_{\mathrm{II}} \mathrm{dn}_{3}$, виходи якої найкраще представлені на Горі Калитві (рис. 11). Флювіогляціальні відклади Калитви є дуже дислоковані, косошаруваті, різноманітні за гранулометричним складом, іноді містять вуглефіковані залишки рослин, фрагменти скам'янілої деревини. Важливою ознакою гляціодислокацій Калитви як кінцевоморенного утворення $є$ відторженці палеогенових порід серед четвертинних відкладів (Manyuk, 1996).
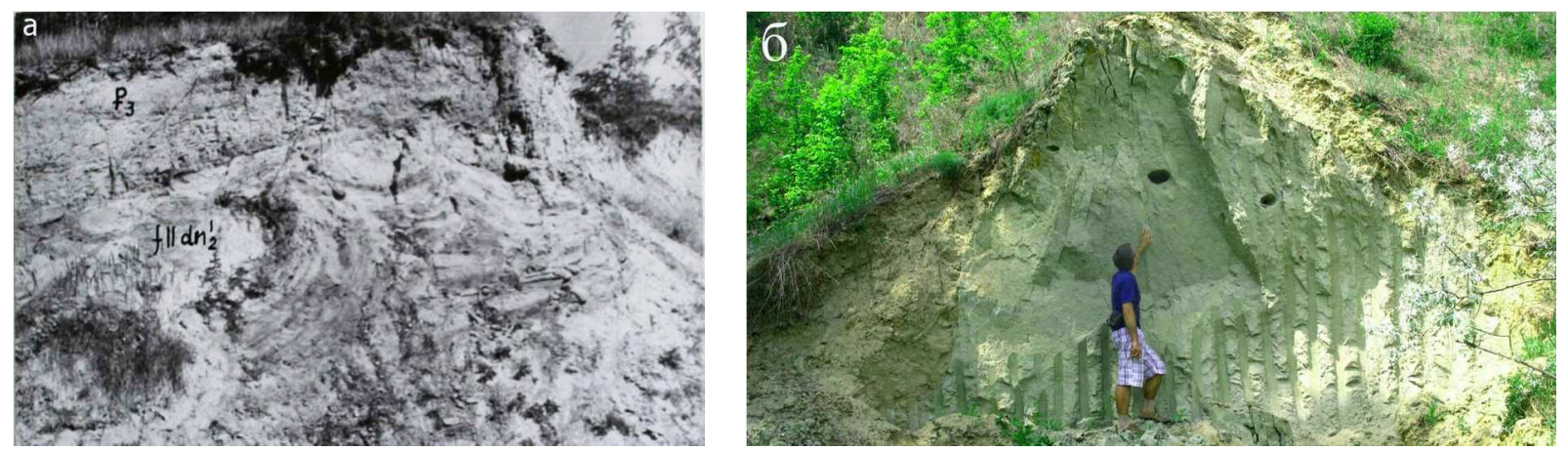

Рис. 11. Гляціодислокації товщі флювіогляціальних пісків (а) та відторженець палеогенових порід на Горі Калитві (б)

Перигляціальна зона, розташована південніше лінії Вільногірськ - Петриківка - Юр'ївка, відрізняється відсутністю валунних суглинків, значно більш однорідним і витриманим розрізом субаеральних четвертинних відкладів, але наявністю лінз флювіогляціальних відкладів. 
В описаннях відслонень і свердловин у матеріалах геологічних зйомок різних років Дніпродзержинського і Дніпропетровського аркушів (1:200 000) можна натрапити на очевидну присутність у деяких розрізах озернольдовикових та флювіогляціальних відкладів. Це зафіксовано лише у наведеному фактичному матеріалі, але не знайшло відображення у графічних і текстових звітних матеріалах, що зро- зуміло 3 огляду на те, що визнана межа поширення дніпровського зледеніння проходить значно північніше. Вперше це «табу» було порушене нами під час проведення геологічного довивчення частини площі аркушів М-36-129 та 141 (Schurko M., 2007), коли ділянки поширення лімно- і флювіогляціальних відкладів були показані у розрізах та на карті четвертинних відкладів (Manyuk, 2005, 2013a, 2017) (рис. 12).
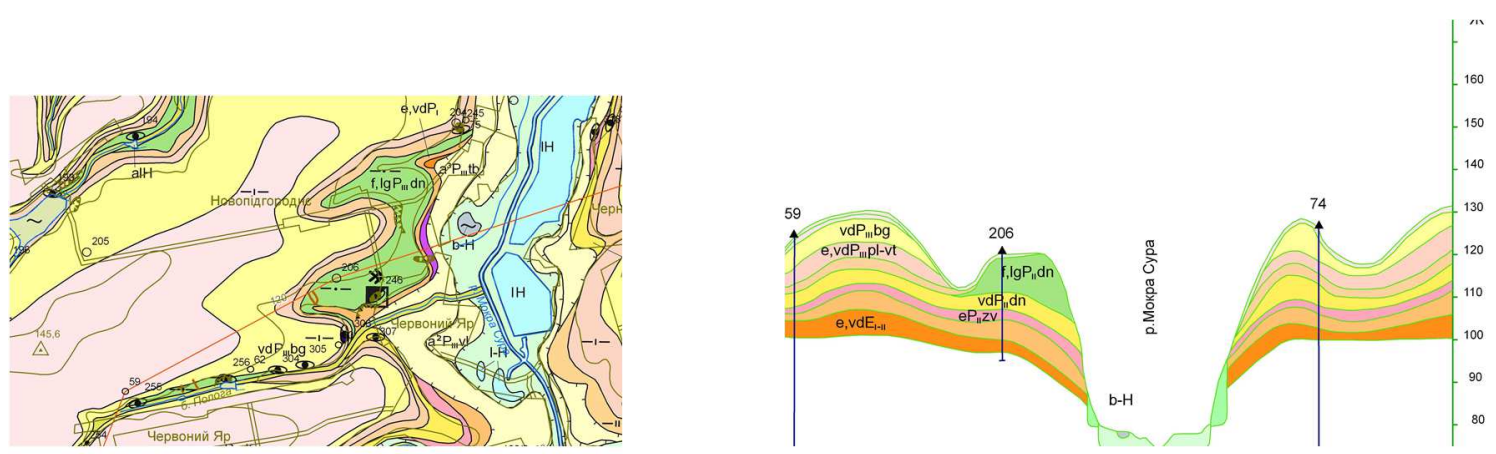

Рис. 12. Озерно-льодовикові та флювіогляціальні відклади дніпровської льодовикової епохи на карті та в розрізі.

Польовими дослідженнями 2011-2012 років у межиріччі річок Дніпро - Кільчень - Самара встановлено переконливі докази необхідності проведення південної межі перигляціальної зони дніпровської льодовикової епохи значно південніше прийнятої. У затвердженій схемі районування четвертинних відкладів межа поширення льодовикових відкладів проведена на підставі «Мапи України...», складеної М.I. Дмитрієвим ще у 1931році. Вона обмежується пригирловою частиною р. Оріль у ії старому річищі.

Між селами Підгородне і Спаське, у каp'єрі з видобутку суглинків у 2012 р. розкрито надзвичайно інформативний розріз четвертин-

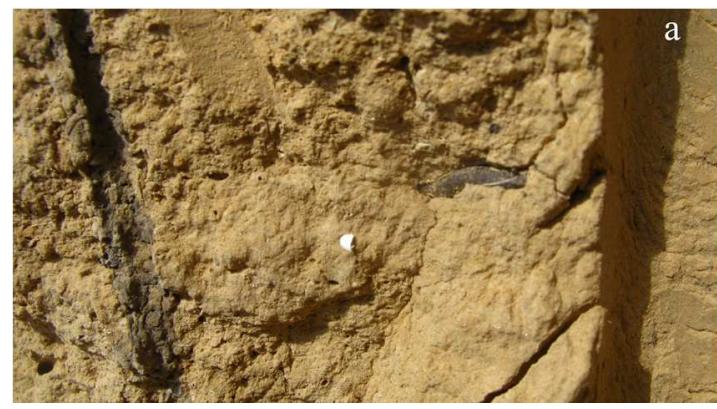

них відкладів. Під шаром сірого кодацького грунту $\left(\mathrm{eP}_{\text {III }} \mathrm{kd}\right)$ потужністю до 1,0 м відслонюється товща тонкошаруватого палевокоричневого суглинку потужністю до 3,5 м. В одній із стінок кар'єру встановлений чіткий контакт озерно-льодовикових суглинків із червонобурими суглинками завадівського термоміру. Виявлене штучне відслонення лімногляціальних відкладів дозволяє не тільки побачити виразні ознаки відмінності еолових і озерних суглинків, але й вточнити границю перигляціальної зони дніпровського зледеніння, яка раніше проводилася майже на 100 км північніше - у пригирловій частині р. Оріль.

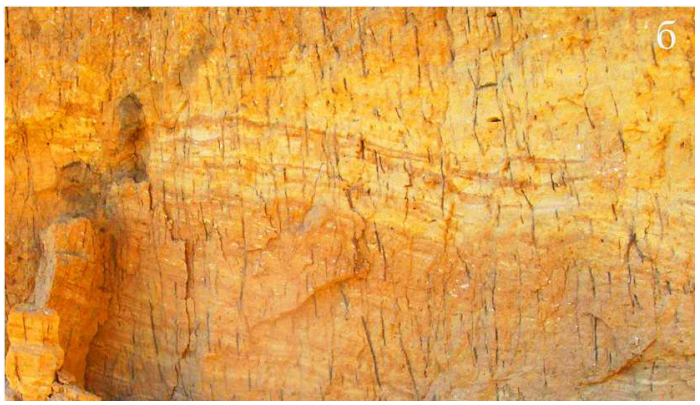

Рис.13. Валунні суглинки дніпровської морени (а) й озерно-льодовикові глини біля с. Спаське

Висновки. Південним бар'єром поширення як лімно- так і флювіогляціальних відкладів пізньольодовиковоі фази дніпровського зледеніння очевидно було підняття кристалічного фундаменту на широті м. Дніпропетровськ. Не випадково в Рибальському кар'єрі, розташованому поблизу місця впадання р. Самара у Дніпро, розкрито незвичний, унікальний для цього району розріз флювіогляціальних відкладів. Під шаром кодацького грунту в одному з уступів кар'єру відслонюється товща кварцового сіруватожовтого піску з нечітко відбитою горизонтальною верствуватістю, з тонкими прошарками вохристо-жовтої озалізненої глини ( $\left.\mathrm{fgP}_{\mathrm{II}} \mathrm{dn}\right)$ загальною потужністю 2,0 м. Нижче у розрізі відслонюється своєрідна товща несортованого уламкового матеріалу з розмірами окремих брил до 0,6 м. Уламки як кутуваті, необкатані, так і доб- 
ре обкатані, слабо зцементовані гравійнопіщаним матеріалом. За складом це гнейси, граніти, кварц і навіть кварцитовидні пісковики, брили яких зустрічаються у пісках полтавської cepiï.

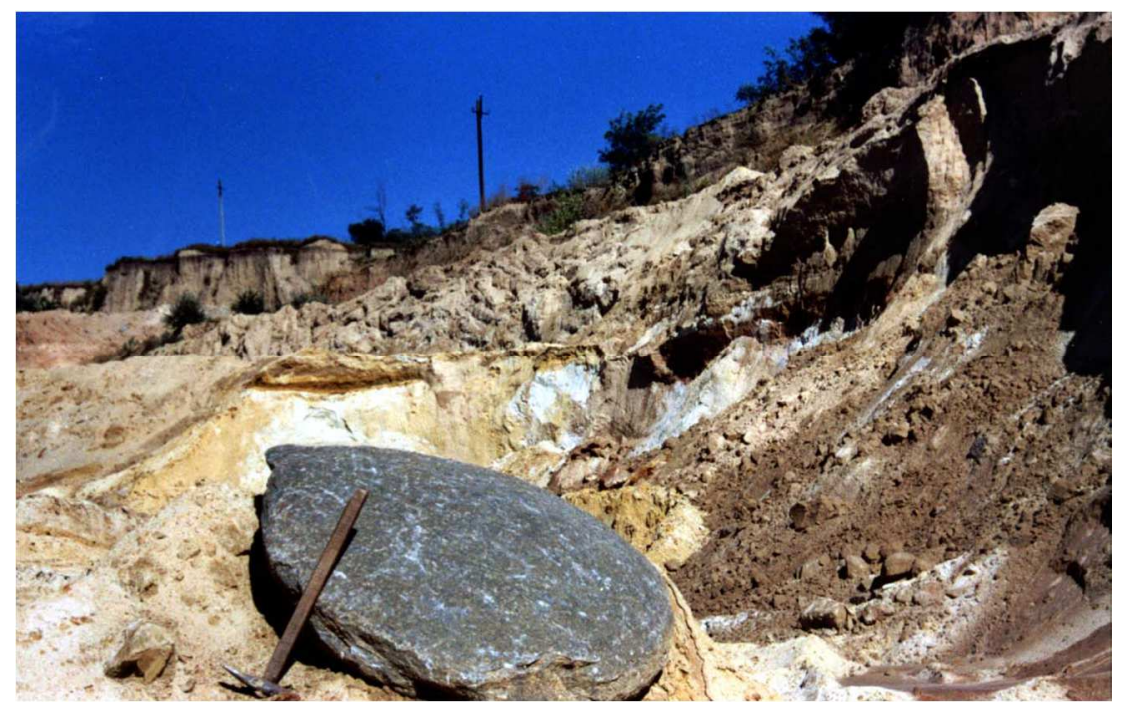

Рис. 14. Ератичний валун та відслонення флювіогляціальних відкладів у Рибальському кар'єрі (Дніпропетровська область)

Потужність прошарку з уламками до 1,0м. Нижче залягають мандриківські верстви верхнього еоцену (Manyuk, 2014). Цілком доцільно припустити, що флювіогляціальні відклади були поширені на значно більшій площі понижених ді-

\section{Бібліографічні посилання}

Agassiz, L. 1838. Observations sur le glaciers. Bulletin de la Societie Geologique de France, V.9 (18371839), 443-450. Retrieved from http://books.google.com/books?id=w3i7AAAAI AAJ\&pg=PA443

Agassiz, L. 1838. On the Erratic Blocks of the Jura. The Edinburgh New Philosophical Journal v.24 (Oct. 1837-April 1838), 176-179. Access: http://books.google.com/books?id=B1sEAAAA YAAJ\&pg=PA176

Agassiz, L. 1840. Glaciers, and the evidence of their having once existed in Scotland, Ireland, and England. Proceedings of The Geological Society of London v.III (Nov. 1838 to June 1842), Part II (1840-1841), 72 327-332. Retrieved from

http://www.google.com/books?id=giPPAAAA MAAJ\&pg=PA327

Agassiz, Louis; Bettannier, Joseph, 1840. Études sur les glaciers. Ouvrage accompagné d'un atlas de 32 planches, Neuchâtel. H. Nicolet, 346.

Andersen, Bjørn G., 1992. "Jens Esmark-a pioneer in glacial geology". Boreas. 21: 97-102. doi:10.1111/j.1502-3885.1992.tb00016.x.

Bernhardi, R. 1832. Wie kamen die aus dem Norden stammenden Felsbruchstücke und Geschiebe, welche man in Norddeutschland und den benachbarten Ländern findet, an ihre gegenwärtigen лянок рельєфу, які слугували каналами стікання талих вод, а в подальшому були використані для закладання річкової мережі Дніпра та його приток і алювісм якого заміщені.

dorte? Jahrbuch für Mineralogie, Geognosie Geologie und Petrefaktenkunde, 257-267 Heidelberg, Georg Reichard [How did the deposits and erratics come from the north to the locations in which one finds them now in Northern Germany and the neighboring countries?]. Retrieved from http://books.google.com/books?id=Nvg3AAAA MAAJ\&pg=PA257

Buch, L., 1819. Additions au memoire sur les causes du transport des blocs des transport des Alpes sur le Jura. Annales de Chimie et de Physique t.10, 241-264 [A detailed review of the ideas of von Buch and de Luc by M. Brochant-de-Villiers.] Access: http://books.google.com/books?id=zJc5AAAAc AAJ\&pg=PA241

Cuvier, G., Brongniart, A. 1811. Essai sur la Géographie Minéralogique des Environs de Paris. Retrieved from

http://books.google.com/books?id=HQQTAAA AMAAJ\&pg=PP7

De Charpentier, Jean. 1841. Essais sur les glaciers et sur le terrain erratique du bassin du Rhône, Lausanne, 412.

De Luc, J.A. 1810. Geological travels. Observations one same parts of the coasts of the Baltic, and the North sea. vol.1 (Rivington, London). Access: http://www.google.com/books?id=se44AAAA MAAJ\&pg=PP7 
Dmitriєv, M.I. 1931. Formy poverhni Ukraïny, vitvoreni bezposeredn'o l'odovykom. [Forms of the surface of Ukraine, created directly by the glacier]. Collection of memory acad. P.A.Tutkovskyi, VAN, 1931, 51-75 (in Ukrainian).

Dokuchaev, V. V. 1877. O rasprostranenii erraticheskih valunov v Rossii i o haraktere nashih juzhnyh nanosov. [On the distribution of erratic boulders in Russia and the nature of our southern sediments]. Pr. St. Petersburg. Society of Natural Sciences. V. 8, Dep. geol. and mineral, 111 (in Russian).

Dokuchaev, V. V. 1892. Nashi stepi prezhde i teper': (Pochvovedcheskij ocherk). [Our steppes before and now: (Soil sciences essay)]. Governmental messenger. Ed. SPb .: typ. E. Evdokimova, 27, IV, 21(in Russian).

Ferhmin, A. R. 1891. Kobyljakskij uezd. Mater. k ocenke zemel' Poltavskoi gub. Issue VIII (in Russian).

Gerasimov, I.P., Markov, K.K. 1939. Lednikovyi period na territorii SSSR. Fiziko-geograficheskie uslovija lednikovogo perioda. [Ice Age in the territory of the USSR. Physico-geographical conditions of the glacial period]. Moscow Leningrad, Academy of Sciences of the USSR, 462 (in Russian).

Glaciers online. 2017. Retrieved from: http://www.swisseduc.ch/glaciers/alps/rhoneglet scher/see 2007-en.html?id=7

Hall, J. 1812. On the Revolutions of the Earth's Surface, being an account of the diluvian facts in the neighbourhood of Edinburgh. Part 1 Transactions of the Royal Society of Edinburgh, V. 5, 139-167; Part 2, V. 7, 169-211. Access: http://vin.12.sentex.ca/ tcc/GT/Hall.html

Karjakin, L.O. 1921. O geologicheskom stroenii gory Kalitvy. [About the geological structure of Kalitva Mountain]. Proc. Kharkov nature society, V.51, issue 2 (in Russian).

Kropotkin, P.A. 1876. Issledovanija o lednikovom periode. [Studies on the glacial period]. (Notes of the Imperial Russian Geographical Society on General Geography, Vol. 7), St. Petersburg, XXXIX, 717, 1-70 (in Russian).

Krüger, Tobias (2013a). Discovering the Ice Ages. International Reception and Consequences for a Historical Understanding of Climate (German edition: Basel 2008). Leiden. 47.

Krüger, Tobias (2013b). Discovering the Ice Ages. International Reception and Consequences for a Historical Understanding of Climate (German edition: Basel 2008). Leiden. 78-83.

Krüger, Tobias (2013d). Discovering the Ice Ages. International Reception and Consequences for a Historical Understanding of Climate (German edition: Basel 2008). Leiden. 150.

Krüger, Tobias (2013e). Discovering the Ice Ages. International Reception and Consequences for a Historical Understanding of Climate (German edition: Basel 2008). Leiden. 155-159.
Krüger, Tobias (2013f). Discovering the Ice Ages. International Reception and Consequences for a Historical Understanding of Climate (German edition: Basel 2008). Leiden. 181-184.

Krüger, Tobias (2013c). Discovering the Ice Ages. International Reception and Consequences for a Historical Understanding of Climate (German edition: Basel 2008). Leiden. 91-96.

Kuhn, B.F. 1787. Versuch fiber den Mechanismus der Gletscher (Investigation into the mechanism of glaciers), 325-336 in G.R. de Beer (trans.) Bernhard Friedrich Kuhn's investigations on glaciers. Annals of Science, v.9 (4 - December), 323-341 ORIGINAL Retrieved from: http://books.google.com/books?id=1Zc5AAAAc AAJ\&pg=PA119\#v

Manyuk, V.V. 1996. Osobennosti dneprovskogo oledenenija $\mathrm{v}$ nizhnem techenii Vorskly. [Features of the Dnieper glaciation in the lower Vorskla]. Questions of geology, geography and environmental protection. Dnepropetrovsk, DGU, 7-8 (in Russian).

Manyuk, V.V. 2005. Pro neobhidnist' detal'nogo rozchlenuvannja chetvertynnyh vidkladiv $\mathrm{V}$ procesi geologo-zjomochnyh robit. [On the need for a detailed dissection of Quaternary deposits in the process of geological survey. Materials of scientific and practical confer. "Current state and tasks of development of regional geological research." Rivne, September 8-15, Kyiv, 178-183.

Manyuk, V.V. 2013. Korotkyi ogliad gipotez pohodzhennia lesiv ta lesovydnyh suglynkiv na prykladi seredn'ogo Prydniprov'ia. [A brief overview of the hypotheses of the origin of loesses and loessal loams on the example of the Middle Dnieper]. "Modern problems of geology": Scientific works devoted to the 155th anniversary of the birth of academician Pavel Apollonovich Tutkovskyi - K., 172-176.

Manyuk, V.V. 2013. Osoblyvosti budovy chetvertynnyh vidkladiv u typovyh rozrizah Seredn'ogo Prydniprov'ja. [Features of the structure of Quaternary deposits in typical sections of the Middle Dnieper]. The Bulletin of the DNU, series: geology, geography. Dnipropetrovsk, V.21, issue 15,3 / 2, 8 - 14 .

Manyuk, V.V. 2014. Chetvertynni vidklady u Rybal's'komu kar'jeri Dnipropetrovs'ka. [Quaternary deposits in the Rybalsky quarry in the city of Dnipropetrovsk]. The Bulletin of the DNU, series: geology, geography. Dnipropetrovsk, V.22,issue 16, 3 / 2, 107 - 111.

Manyuk, V.V. 2017. Novi dani pro polozhennia Pivdennoi' granyci Dniprovs'kogo zledeninnia. [New data on the position of the southern boundary of the Dnipro glaciation]. 40 years for the Paleontological Society of Ukraine: materials of the XXXVIII session of the Paleontological Society of the National Academy of Sciences of Ukraine (Kaniv, May 23-26, 2017) Kyiv, 2017, 176-178. 
Markov, K. K. 1986. Paleogeografia i novejshie otlozhenija. [Paleogeography and the newest deposits]. M .: Nauka, 1- 380.

Martel, P. 1744. An account of the glacieres or ice alps in Savoy, in two letters, one from an English gentleman to his friend at Geneva; the other from Pierre Martel, engineer, to the said English gentleman". In Mathews, C.E. The annals of Mont Blanc. London: Unwin. p. 327.

Mirchink, G.F. 1923. Posletretichnye otlozhenija Chernigovskoj gubernii i ih otnoshenie $\mathrm{k}$ analogichnym otlozhenijam Evropejskoj Rossii. [PostTertiary deposits of the Chernigov province and their relation to similar deposits of European Russia]. V.2, Appl. 1, Vestn. Moscow. Horn. Acad.

Nikitin, S.N. 1885. Predely rasprostranenija lednikovyh osadkov v central'noi Rossii i na Urale. [Limits of the distribution of glacial sediments in central Russia and the Urals]. Izv. Geol. com., 4, 3-12.

Pazynych, V.G. 2007. Geomorfologichnyi litopys Velykogo Dnipra. Kiev-Nizhyn: AspectPolygraph,1-24.

Penck, A., Brückner, E. 1909. Die Alpen im Eiszeitatler, Bd.1 -3, Reimpresso por C.H., Touchitz.

Pidoplichko, I.G. 1946. O lednikovom periode. Vypusk 1. Vozniknovenie i razvitie uchenija o lednikovom periode. [On the Ice Age]. Issue 1. The emergence and development of the theory of the glacial period. Kyiv State University, 1-171.
Playfair, J. 1802. Illustrations of the Huttonian Theory of the Earth in, The Works of John Playfair, 1822 (Archibald Constable \& Co., Edinburgh), http://books.google.com/ books?id=MMkEAAAAYAAJ\&pg=PP11

Saussure de, H.-B. 1796 Agenda, ou tableau generale dès observations \& des secherches dont les résultats doivent servir de base à la théorie de là terre, Chapter VIII, Observations à faire sur les cailloux roulés p.483-484 in Voyages dans les Alpes précédés d'un essai sur l'histoire naturelle des environs de Geneve, Volume IV (Louis Fauche-Borel, Neuchatel) Retrieved from: http://books.google.com/books?id=RJcaAAAA YAAJ\&pg=PA483\#v

Sobolev, D.N. 1926. Priroda Kanevskih dislokacij. [Nature of the Kanev dislocations]. Bulletin of the Moscow. Soc. Tried. Nat. Depart. Geol., V. IV (3-4).

Venetz, I. 1821. Mémoire sur les variations de la température dans les Alpes de la Suisse. Par M. VeÎvetz,, ingénieur en chef du canton du Valais, v.1(2) p.1-38. Retrieved from: http://www.google.com/books?id=cLoEAAAA QAAJ\&pg=RA1-PA1

Zamoryi, P.K. 1961. Chetvertynni vidklady Ukraïns'koï RSR. [Quaternary deposits of the Ukrainian SSR]. Kyiv University, 436-450. 